\title{
A Study to Compare the Post Surgical Outcome Using Conventional Suture Material and Stapler for Wound Closure
}

\author{
Santosh Kumar', Shri Krishna Ranjan² \\ ${ }^{1}$ Assistant Professor, Department of Surgery, Anugrah Narayan Magadh Medical College and Hospital, Gaya, ${ }^{2}$ Associate Professor, Department of \\ Surgery, Anugrah Narayan Magadh Medical College and Hospital, Gaya.
}

\section{Abstract}

Background: Tissue repair following skin incisions should be with good strength with least tissue damage and less inflammation with aesthetically acceptable scar. Aim: The aim of this study is to compare two skin closure techniques - suture and stapler in open abdominal surgeries. Subjects and Methods: 160 sequentially admitted patients were divided into 2 groups and one underwent stapler suturing and the other underwent conventional suturing. We measured the length of the incision sutured per minute, pain score, scar type, expenses and wound infections. Results: The incidence of Wound infection, pain score, time taken for suturing are lesser in stapler group compared to Conventional group. Cost wise the Conventional type of suturing is cheaper than the Stapler method. Conclusion: Wound closure with staples is almost three times faster thus time saving.

Keywords: Wound healing, skin stapler, conventional skin suturing.

Corresponding Author: Dr. Shri Krishna Ranjan, Associate Professor, Department of Surgery, Anugrah Narayan Magadh Medical College and Hospital, Gaya.

Received: October 2019

Accepted: October 2019

\section{Introduction}

The skin is an organ of astonishing complexity. It is a barrier between the human body and external environment and is protective and self repairing .It is strong, elastic, and water- resistant and acts as a sense organ to a number of stimuli. The skin is also the largest organ of the body and also the protective covering. ${ }^{[1-5]}$

When the surgeon suture a clean incision, healing takes place with minimum loss of tissue and without significant bacterial infection with minimal scarring, With passage of time and availability of newer methods of skin closure, it has become an art with stress on better cosmetic results. Any method of skin closure should provide adequate approximation of the tissue to allow wound healing with minimal risk of infection and should produce an acceptable cosmetic result. The method should be simple, quick to use and cost effective. ${ }^{[6-9]}$ Since long the art of suturing is emerging continuously for the betterment of the patient in terms of cosmetic appearance -minimal scar, decreasing the risk of infection better patient compliance thus overall decreasing the morbidity. ${ }^{[10]}$ The aim of this study is to compare two skin closure techniques - suture and stapler in open abdominal surgeries.

\section{Subjects and Methods}

This prospective study was conducted at ANMMCh, Gaya. The study was approved by the institutional research committee. A total of 160 cases were included in this study with prior informed consent. The study was carried out over a time period of six months. The present study was observational, and comparative.

The criteria for inclusion were- All patients getting admitted to the Department of general surgery and requiring elective surgery. Surgeries in which linear abdominal skin incisions are performed. Length of the skin incision $>5 \mathrm{cms}$. All patients in the age group between 15-60 yrs willing for participation in the study after obtaining informed consent. The criteria for exclusion were- Psychiatric patients , Immuno compromised states like TB, and Hepatitis B. Patients having uncontrolled Diabetes. Patients who refused to cooperate for the entire study period. Pregnant women

After the surgery, the subcutaneous fat was sutured with 2-0 Vicryl, and

1. Suture Group (A) : Skin was approximated with plain interrupted sutures using non-absorbable 2-0 silk at a distance of $1 \mathrm{~cm}$ from each other.

2. Stapled Group (B): The staples are used to close the wound and are placed at a distance of $5 \mathrm{~mm}$ from one another.

Each wound was closed with plain interrupted silk sutures in group 'A' and with staples in group ' $B$ ' after 
achieving haemostasis. All wounds were closed by a single operator to get uniform results. Time taken for skin approximation was measured by an independent observer, wounds after cleaning with povidone-iodine lotion and sterile dry gauge dressing applied and covered with adhesive plaster. The signs of inflammation (redness, oedema), discharge (serous, seropurulent, purulent), dehiscence (partial, complete) was assessed.

\section{Result}

This comparative study was done over a period of 6 months at ANMMCH, Gaya. 160 cases were studied and were randomly divided in two groups each of 80 cases: The results were analyzed from the observations made and are tabulated as follows-

The mean age of the subjects participating in the study was $44.56 \pm 14.9$, the mean age of the participating subjects in the stapler group was $43.08 \pm 17.7$ and that in the suture group was $46.04 \pm 16.0$. Distribution of subjects in different age group is shown in [Table 1].

Table 1: Distribution of subjects in different age group.

\begin{tabular}{|c|c|c|c|c|c|c|}
\hline & \multicolumn{2}{|c|}{ Group A $(n=80)$} & \multicolumn{2}{|c|}{ Group B (n=80) } & \multicolumn{2}{|l|}{ Total } \\
\hline $\begin{array}{l}\text { Age } \\
\text { (years) }\end{array}$ & Number & $\%$ & Number & $\%$ & Number & $\%$ \\
\hline $15-20$ & 14 & 18 & 12 & 15 & 26 & 15 \\
\hline $21-30$ & 10 & 13 & 11 & 14 & 21 & 12 \\
\hline $31-40$ & 25 & 31 & 16 & 20 & 41 & 23 \\
\hline $41-50$ & 21 & 26 & 25 & 31 & 46 & 26 \\
\hline $51-60$ & 10 & 13 & 16 & 20 & 26 & 15 \\
\hline Total & 80 & 100 & 80 & 100 & 160 & 100 \\
\hline
\end{tabular}

The distribution of subjects amongst the gender showed, the number of males were 112 and the number of females were 68. [Fig 1].

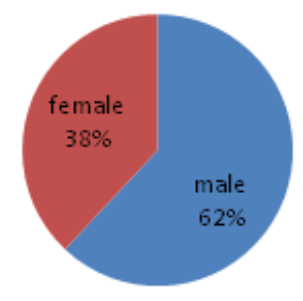

Figure 1: Distribution Of Subjects Amongst Gender

Table 2: Relation Of Wound Length With Closure Time And Cost.

\begin{tabular}{|l|l|l|}
\hline & Sutures & Staples \\
\hline Average wound length (in cm) & 7.32 & 7.5 \\
\hline Time taken / wound (in mins) & 9.8 & 7.3 \\
\hline Time taken / cm wound (in sec) & 45 & 15 \\
\hline Number of staples / sutures /wound & 9.4 & 8.1 \\
\hline Time taken / suture or staple & 12.54 & 8.74 \\
\hline Average cost / wound & 80 & 160 \\
\hline
\end{tabular}

The study result showed that, the average wound length in the suture group was $7.32 \mathrm{~cm}$ and that in the staple group was $7.5 \mathrm{~cm}$. The time taken to close the surgical wound was statistically different in the two group with the suturing using traditional suture material took significantly more time compared to the staples. The traditional suturing technique also required more number of sutures compared to the staples for the same length of wound. in contract the coat of the stapler was double the cost of the suture material. [Table-2]

Table 3: Incidence of inflammation, discharge and dehiscence.

\begin{tabular}{|l|l|l|}
\hline \multicolumn{2}{|l|}{ Sutures (\%) } & Staples (\%) \\
\hline Signs of inflammation & 20 & 10 \\
\hline Redness & 10 & 20 \\
\hline Swelling & \multicolumn{2}{|l|}{} \\
\hline Discharge & 10 & 10 \\
\hline Serous & 00 & 00 \\
\hline Seropurulent & 00 & 00 \\
\hline Purulent & \multicolumn{2}{|l|}{} \\
\hline Dehiscence & 00 & 00 \\
\hline Partial & 00 & 00 \\
\hline Complete & & \\
\hline
\end{tabular}

The nature of response after wound closure showed inconclusive result in terms of choice of material as the incidence of erythema was more in the suture while tumor was more in the stapler group. Both the materials showed almost similar response to the wound infection. [Table-3]

\section{Discussion}

Wound closure is as important as any other action performed by the surgeon. And apart from the need for producing a healthy and strong scar, it is the surgeon's responsibility to ensure its aesthetically pleasing physical appearance. Skin staples are an alternative to regular sutures in offering this advantage.

Sutures are used to facilitate the process of wound healing by:

1. Closing dead space within wound

2. Supporting wounds until their tensile strength is increased

3. Approximating skin edges.

Sutures initiate a foreign body response (i.e. tissue reaction). The initial tissue reaction is attributed to the injury inflicted by the passage of suture and needle and reaction to the suture material itself. The reaction of living tissue to injury or foreign bodies is called inflammation. The inflammatory response usually peaks between 2 to 7 days after implantation. The longer a suture mass stays in the human body, the more likely it is to produce undesirable tissue reactions. For the surgeon, a scar may be the only trademark of the surgical procedure performed, as FitzGibbon has stated, "By your scars you will be judged." (Fitz Gibbon, 1968).

In our present study, Regarding post operative surgical site infection on 3rd day infection is three times more in suture than in stapler which was justified by the study of Stillman and colleagues. ${ }^{[11]}$ On the 7 th post operative day infection is two times more in suture than in stapler which is correlated with the study of Iavazzo and Gkegkes ID. ${ }^{[12-13]}$

Regarding post operative pain over surgical site, wound pain is more in suture group patients, than in stapler group patients, which is correlated with the study of 
Ritchie $\mathrm{AJ}^{[14]}$ and with the study of D. Gatt, C. R. Quick. ${ }^{[15]}$ Regarding post operative wound discharge and dehiscence, wound dehiscence was not found in any case of the two group. The incidence of discharge was similar in both group, this is in contrast to the study of Stillman and colleagues $^{[16]}$ and with the study of Vouloumangu EK. ${ }^{[17]}$

\section{Conclusion}

In this study time taken to close a wound with staples was almost three times faster than with sutures, signs of inflammation were more or less equal and wound dehiscence was zero in both the groups. Average cost per wound closure was very high with staples v/s sutures.

\section{References}

1. Medina dos Santos LR, Freitas CAF, Hojaji FC et al. Prospective study using skin staplers in head and neck surgery. AM J Surg. 1995; 170-451-452.

2. George TK, Simpson DC. Skin wound closure with staples in the Accident and Emergency Department. J R Coll Surg Edinb 1985; 30:54.

3. Kanegaye JT, Vance CW, Chan L, Schonfeld N. Comparison of skin stapling devices and standard sutures for pediatric scalp lacerations: a randomized study of cost and time benefits. J Pediatr 1997; 130:808.

4. Iavazzo C, Gkegkes ID, Vouloumanou EK, Mamais I, Peppas G, Falagas ME. Sutures versus staples for the management of surgical wounds. A meta-analysis of randomized controlled trials. Am Surg. 2011 Sep;77(9):1206-21.

5. Queck CR, Owen Smith MS. Staples for wound closure. A controlled trial, staples v/s two conventional sutures method. Ann
R Coll Surg Engl. 1985;67(5):318-20.

6. Stockley I, Elson RA. Skin closure using staples and nylon sutures. A comparison of results. Ann R Coll Surg Engl. 2005;69(2):76-8.

7. S. S. Karbhari, Avinash K. Bhavikatti. Study of skin staples ad conventional sutures for abdominal skin wound closure. Int $\mathrm{J}$ Biomed Adv Res. 2012;03(07):552-4.

8. Ghosh A, Nanjappa M, Nagaraj V, Rajkumar GC. Comparison between stainless steel staples and silk sutures for primary closure of skin in patients undergoing neck dissection. A comparative clinical study. Contemp Clin Dent. 2015;6(Suppl 1):S51-5.

9. Orlinshky M. Goldberg, R. M. Chan L. Cost analysis of stapling v/s suturing for skin closure. Am J Emerg Med. 1995;13(1):77-81.

10. Bresnahan KA, Howell JM, Wizorek J. Comparison of tensile strength of cyanoacrylate tissue adhesive closure of lacerations v/s sutures closure. Ann Emerg Med. 1995;26(5):575-8.

11. Stillman RM, Bella FJ, Seligman SJ, Skin Wound Closure: The effect of various wound closure methods on susceptibility to infection. Arch Surgery, 1980; 115:674-680.

12. Iavazzo C, Gkegkes ID, Vouloumangu EK, Mamais I, Peppas G, Falagas ME. Randomized controlled trial for suture vs. stapler for management of surgical wounds. Am Surg. 2011 Sep; 77(9):120621.

13. Eldrup Randomized controlled trial compared stapler with conventional skin closure.

14. Ritchie AJ et al carried out a prospective double blind randomized study comparing staples versus sutures in the closure of scalp wound and found that stapling was significantly faster and less painful.

15. Stockley I, ElsoEldrup J, Wied U, Andersen B. Randomised trial comparing Proximate stapler with conventional skin closure. Acta Chir Scand. 1981; 147(7): 501-502.

16. Stillman RM, Bella FJ, Seligman SJ, Skin Wound Closure: The effect of various wound closure methods on susceptibility to infection. Arch Surgery, 1980; 115:674-679.

17. Iavazzo C, Gkegkes ID, Vouloumangu EK, Mamais I, Peppas G, Falagas ME. Randomized controlled trial for suture vs. stapler for management of surgical wounds. Am Surg. 2011 Sep; 77(9):120621.

Copyright: () the author(s), 2019. It is an open-access article distributed under the terms of the Creative Commons Attribution License (CC BY 4.0), which permits authors to retain ownership of the copyright for their content, and allow anyone to download, reuse, reprint, modify, distribute and/or copy the content as long as the original authors and source are cited.

How to cite this article: Kumar S, Ranjan SK. A Study to Compare the Post Surgical Outcome Using Conventional Suture Material and Stapler for Wound Closure. Acad. J Surg. 2019;2(2):34-36.

DOI: dx.doi.org/10.21276/ajs.2019.2.2.9 